\title{
Effect of Using Raw or Processed Lablab Seed as Major Protein Source in Diets on the Economic of Feeding and Growth Performance of Rabbits
}

\author{
D.T. Shaahu, S.N. Carew, N.E. Dzungwe \\ Department of Animal Production, Collage of Animal Science, University of Agriculture, Makurdi. \\ PMB 2373, Makurdi, Benue State, Nigeria.
}

\begin{abstract}
The study was carried out to determine growth performance and economics benefit of feeding raw or processed lablab purpureus seeds to growing rabbits. The lablab seeds were either left raw, processed by decortication, toasting or boiling; and respectively incorporated into diets T2, T3, T4 and T5 to provide 75\% of protein provided by full fat soyabean (FFSB) in the control diet (T1). Thirty, 5-weeks old mixed bred rabbits of 350-358g were used in a completely randomized design. Rabbits fed heat treated seed diets grew faster than those fed raw or decorticated seed diets. Rabbits fed the control diet were however heavier than those fed the heat treated lablab seed diets. More money was expended on rabbit fed either raw or decorticated lablab seed diets to gain $1 \mathrm{~kg}$ live weight than those fed heat processed lablab diets. The control diets were outstanding in terms of gain per kilogram live weight. It was observed that feeding of raw or decorticated Lablab seed in diets to growing rabbits resulted to high cost of feeding, poor growth rate and subsequently death of rabbits fed the raw lablab seed diet. This suggests that Lablab seeds be processed possibly by cooking before use in monogastric diets.
\end{abstract}

Key words: Highworth Seed, Lablab, Protein Source, Rabbits

\section{Introduction}

The lablab bean (Dolichos lablab or Lablab purpureus) is a legume very similar in appearance to the velvet bean. Like other legume seeds, the nutritional value of lablab purpureus beans is shrouded by the presence of antinutritional factors such as tannins, phytate, and trypsin inhibitors, [1]; [2], which would limit its use in monogastric nutrition. They thus require to be suitably processed to eliminate or reduce these antinutritional factors. Effective utilization of this legume can be achieved by reduction or complete illumination of these antinutritional factors. Heat treatment has been employed to reduce or totally eliminate the anti-nutritional factors contained in legume seeds [3]; [4]; [5] and [6]. Reports have shown that boiling, toasting, fermentation, sprouting, decorticating of seeds and chemical treatment, can reduce or eliminate the anti-nutritional factors in legume seeds. There is only pocket-size knowledge about the effect of these processing methods on the nutritive value of lablab seeds to rabbits. The study is aimed at determining the processing effects on the seed of lablab in the nutrition of rabbits.

\section{Materials and methods}

The study was conducted at the University of Agriculture, Makurdi Livestock Teaching and Research Farm. Makurdi is the capital of Benue State which lies within Latitude $7^{\circ} 43^{`}$ North and Longitude $8^{\circ} 3^{`}$ East with ambient temperature range of $17.3^{\circ} \mathrm{C}-35.6^{\circ} \mathrm{C}$, and a relative humidity of $47-85 \%$ [7]. The ambient temperature has recently reached $40^{\circ} \mathrm{C}$ during February and March, 2010. The lablab purpureus beans used was the Highworth variety was obtained from the National Animal Production Research Institute (NAPRI), Zaria, Nigeria.

Four equal quantities of the raw lablab seed samples were subjected to different processing procedures. One of the samples was decorticated; the raw lablab seed was cracked in a milling machine to separate the cortex from the seed. The second lablab seed sample was toasted; the seeds was poured directly in a hot toasting pot and agitated (to prevent the seeds from getting burnt) till the seed cortex flaked, producing the characteristics aroma of toasted seed. The Third sample was boiled; water was brought to a boiling point and the seed were added to it, after both the water and the seed begins to boil [8], it was timed to 40 minutes; water was drained off, and the seeds were sun-dried. The Fourth lablab seed sample was left raw. The raw and the processed lablab seed were then milled, ready for chemical analysis, and for inclusion in the test diets (Fig. 1). At the commencement of the experiment, all the rabbits were dewormed with ivomectin and three weeks later with coccidiostat against coccidiosis. Five diets were formulated incorporating toasted full fat soyabean (FFSB) in the control diet (T1) as the main protein source, subsequently the full-fat soyabean was replaced by raw lablab seed, (second diet; T2), decorticated lablab seed, (third diet; T3) toasted lablab seed (fourth diet; T4) and 
cooked lablab seed (fifth diet; T5), to provide $75 \%$ of the dietary protein (CP) contributed by FFSB in the control diet respectively. The quantity of maize in the diet was adjusted to make a $100 \%$ diet (Table 1). Thirty weaned mixed breed (California, New Zealand, American Chinchilla and Dutch) rabbits weighing between 350$358 \mathrm{~g}$ were grouped into five and allotted to the five dietary treatments in a completely randomized design, with 6 rabbits per treatment, each rabbit representing an experimental unit. The animals were housed individually, feed along with water were provided ad libitum. The feeding trial lasted for 5 weeks.

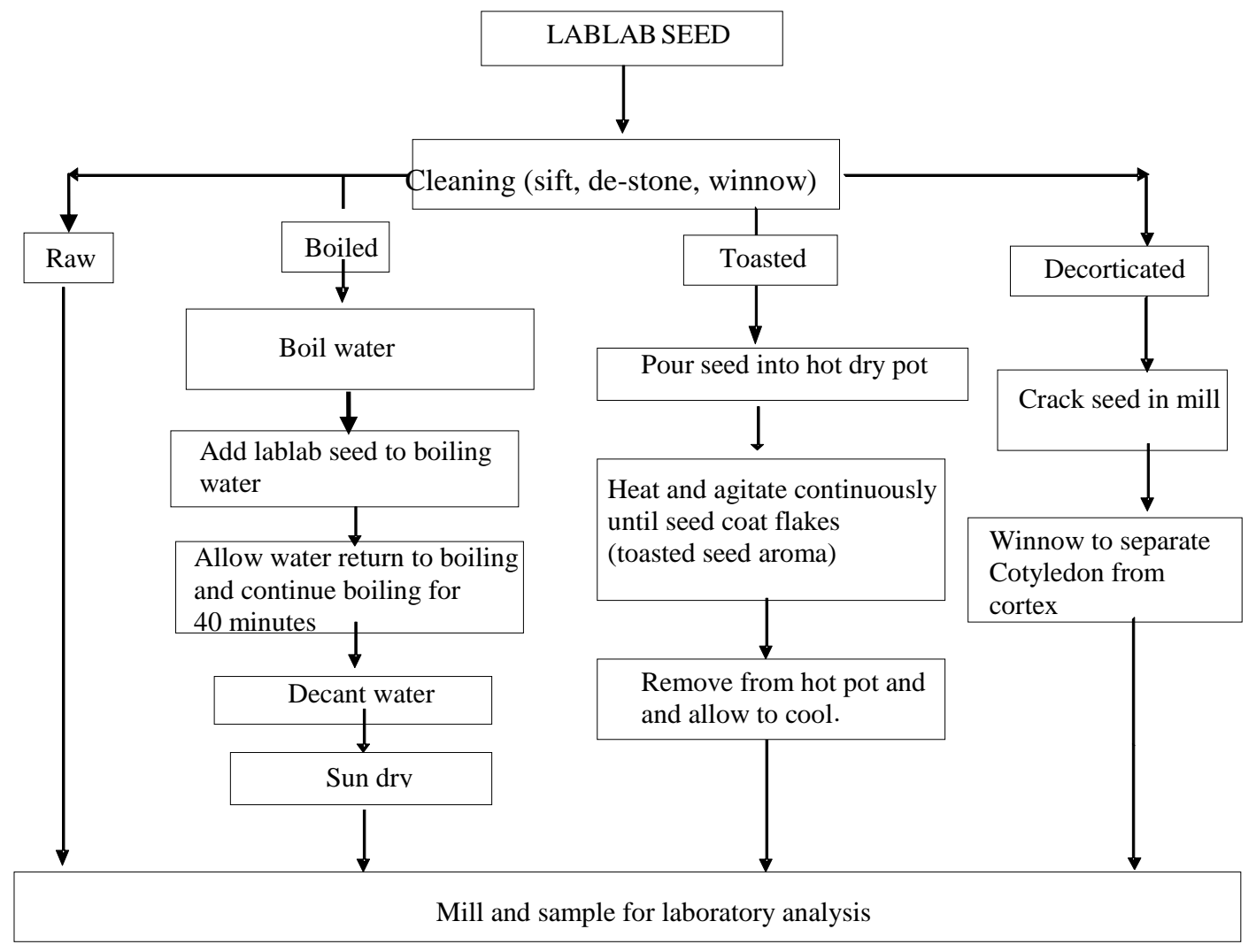

Figure 1: Seed Processing Flow Chart

\section{Results}

Growth performance of rabbits fed lablab seed diets showed that the effects on the total weight gain, average weight gain, feed intake and feed to gain ratio of weaner rabbits were significant $(\mathrm{p}<0.05)$ among treatments (Table 3). The weaner rabbits fed T1 and T5 diets showed significantly $(\mathrm{P}<0.05)$ more weight than $\mathrm{T} 2$ and T3. The rabbits fed T4 diet had similar final weight with those fed T1, T2 and T5 diets but significantly weighed more than those fed T3 diet. The feed intake for weaner rabbits fed T1, T2 and T3 diets were the same $(\mathrm{P}<0.05)$, and significantly $(\mathrm{P}<0.05)$ less than the feed intake of the rabbits fed $\mathrm{T} 4$ and $\mathrm{T} 5$ diets.

The rabbits fed the control diet showed a significantly $(p<0.05)$ more weight gain than those on all the lablab seed diets. The rabbits fed the wet and dry heat processed lablab seed diets had similar $(p>0.05)$ weight gain, on the other hand, these rabbits gained more $(\mathrm{p}<0.05)$ weight than those fed the raw and raw decorticated lablab seed diets. The feed to gain ratio of these rabbits showed similar trend as the weight gains among all the dietary treatments.

The cost of producing one kilogram of the control diet (39.05) was higher than that of the lablab seed diets. The cost of producing raw lablab and that of decorticated lablab seed diets were $\$ 35.17$ and $\$ 34.70$ respectively, while $1 \mathrm{~kg}$ of toasted and boiled lablab seed diets cost $\$ 34.99$ and $\$ 34.64$ respectively. Rabbits fed T2 and T3 diets respectively consumed feed worth $\$ 19.46$ and $\$ 18.36$ only while those fed T4 and T5 consumed feed worth $\$ 26.27$ and $\$ 26.38$ respectively. The feed value ( $\$ 22.30$ ) for rabbits fed the control diet was worth less than that of rabbits fed T2 and T3 but higher than those fed T4 and T5 diets respectively. Rabbits fed T4 and T5 diets required higher cost of feed than those fed T1 diet but lesser cost than rabbits fed T2 and T3 diets respectively to gain $1 \mathrm{~kg}$ live weight. There was a $33 \%$ mortality which was recorded only among the rabbits that consumed $\mathrm{T} 2$. 


\section{Discussion}

Economic and growth performance of rabbits fed lablab seed diets Rabbits fed cooked lablab seed diet performed better than those fed the raw lablab seed diets in the present study. Rabbits fed toasted lablab seed diets also performed significantly better than those fed the decorticated seed diet and numerically superior to those fed raw lablab seed diet. Heat treatment results in the destruction of some anti nutritional factors such as trypsin inhibitors, haemagglutinins, phytic acids and hydrogen cyanide. This improves nutrient availability and utilization of the seed for better performance in monogastric animals. Findings in the present study agree with the work of [9] and [10], who reported that broilers fed cooked lablab seed performed better than those fed the raw lablab seed diets. Better performance has been reported when other legume seeds cooked and fed to broilers compare to those fed raw seeds [11]; [12]. It was found [5] that cooking soyabean seeds for about 30 minutes caused better performance of weaned pigs than cooking for lesser periods.

The average daily weight gain range (6.81-9.24) obtained for rabbits fed the control and heat treated lablab seed diets in the present study were higher than the range (4.20-5.81g/rabbit) reported [13] when he fed rice milling by-products to rabbits. The daily weight gains of the rabbits [13] are higher than those of rabbits fed raw or decorticated lablab seed diets in the present study. The values of the rabbits fed the control diet in the present study are similar to the report [14] when yellow maize was used as the source of energy. The performance values of rabbits fed the treatment diets are less than the values reported [15], according to the author, rabbits at $0-8$ weeks had an average daily weight gain of $20.30 \mathrm{~g}$ with a feed intake of $120 \mathrm{~g}$ and feed efficiency of 2.5-3.5. This was in part attributed to animal effect rather than diet.

The present study findings revealed that the final weights of the rabbits fed toasted lablab seed diets from 0-5 weeks were similar to those fed control diet, and also similar to those fed the raw seed diets. The rabbits fed the cooked lablab seed diet were however significantly superior to those fed the raw lablab seed diets. The finding of this present study agrees with the reported [16] that dry heating (Toasting) of legume seeds are less effective in the removal of antinutritional substances and thus, performance of animals than wet heating. This confirms the reports of other workers [5], [17; they observed better performance in birds fed cooked legume seeds compared to those fed toasted seed diets. Soyabean based control diet in the present study resulted to superior performance (total weight gain, average daily weight gain and feed to gain ratio) than all the test diets. Both toasting and cooking of the lablab seed effectively improved the utilization of lablab seed diets after five weeks of feeding. Decortication of raw lablab seed was not enough to improve its utilization in growing rabbit diet as indicated by performance of rabbits fed raw or decorticated lablab seed diets. This poor performance implicates the cumulative effect of the residual amount of anti-nutritional factors (especially haemagglutinin and trypsin inhibitor) in raw and decorticated lablab seed.

The higher feed intake of rabbits fed the heat treated lablab seeds diets compared to those fed raw or decorticated lablab seed diet suggests that there was improvement in the palatability of the heat treated lablab seeds diets as the anti-nutritional factors were reduced or removed. Antinutritional factors such as saponin and tanin in seeds imposes an astringent property (sharp taste) that adversely affects palatability, reduces feed intake and consequently body growth [18]; [19]. The higher feed intake by the rabbits fed heat treated lablab seed diets compared to the control diet suggests that lablab seed may be more palatable to young rabbits than soyabean seed. According to [20], the rabbit adjusts its feed intake to meet its caloric needs. If fed low energy diet, it eats more feed and when fed high energy diet, intake is less. Energy level cannot be implicated in the present study since the energy contents of the diets are not varied. Lablab seed is also rated among the most palatable of legumes seeds for animals. Feed to gain ratio

The high cost of the control diet is an indication of the low cost of lablab seed compared to soyabean. The variations in the cost among the lablab diets are in response to the different levels of inclusion of lablab and that of maize in the diets. The difference in the cost of feeding the rabbits for 5 weeks with experimental diets is a reflection of the differences in amount of feed consumed and difference in the cost of the respective diets. Feed efficiency on account of cost $/ \mathrm{kg}$ live weight gain was maximized by the rabbit fed the control diet. Among the lablab seed diets, boiled lablab seed diet was more cost effective than the toasted seed diet, while the raw lablab seed diet was more proficient than the decorticated diet among the raw seed diets.

The cause of death of the rabbits fed raw lablab diet (T2) could be attributed to inability of the young rabbits to tolerate the density of the anti nutritional factors in the raw lablab seed at the levels and period fed.

\section{Conclusion}

There was no adverse effect on the economics of feeding and growth performance of rabbits. However, feeding of raw or decorticated Lablab purpureus seed in diets to growing rabbits resulted to high cost of feeding, poor growth rate and subsequently death of rabbits fed the raw lablab seed diet. It is therefore suggested that Lablab purpureus seeds be processed possibly by cooking before use in monogastric diets. 
Table 1: Ingredient Composition of Experimental Diets (\%)

\begin{tabular}{llllll}
\hline Ingredients & $\begin{array}{l}\text { Control } \\
(\mathrm{T} 1)\end{array}$ & $\begin{array}{l}\mathrm{TR} \\
(\mathrm{T} 2)\end{array}$ & $\begin{array}{l}\mathrm{TD} \\
(\mathrm{T} 3)\end{array}$ & $\begin{array}{l}\mathrm{TT} \\
(\mathrm{T} 4)\end{array}$ & $\begin{array}{l}\mathrm{TC} \\
(\mathrm{T} 5)\end{array}$ \\
\hline Maize & 37.28 & 35.36 & 32.27 & 34.69 & 31.85 \\
FFSB & 24.00 & 6.00 & 6.00 & 6.00 & 6.00 \\
Lablab seed & - & 19.92 & 23.01 & 20.59 & 23.43 \\
Rice husk & 26.00 & 26.00 & 26.00 & 26.00 & 26.00 \\
BDG & 9.72 & 9.72 & 9.72 & 9.72 & 9.72 \\
Bone ash & 2.50 & 2.50 & 2.50 & 2.50 & 2.50 \\
Salt & 0.50 & 0.50 & 0.50 & 0.50 & 0.50 \\
Premix * & + & + & + & + & + \\
Total & $\mathbf{1 0 0 . 0 0}$ & $\mathbf{1 0 0 . 0 0}$ & $\mathbf{1 0 0 . 0 0}$ & $\mathbf{1 0 0 . 0 0}$ & $\mathbf{1 0 0 . 0 0}$
\end{tabular}

$\mathrm{TR}=$ Raw lablab seed diet; $\mathrm{TD}=$ decorticated lablab seed diet; $\quad \mathrm{TT}=$ toasted lablab seed diet; $\mathrm{TC}=$ cooked lablab seed diet; $\mathrm{BDG}=$ brewers dried grain; FFSB=full-fat soyabean.

*0.25 of Premix (Agrimix Broiler Starter) manufactured by AGRITED NIG. LTD,

\begin{tabular}{|c|c|c|c|c|c|}
\hline Nutrients & $\begin{array}{l}\text { Control } \\
\text { (T1) }\end{array}$ & $\begin{array}{l}\text { TR } \\
\text { (T2) }\end{array}$ & $\begin{array}{l}\text { TD } \\
\text { (T3) }\end{array}$ & $\begin{array}{l}\text { TT } \\
\text { (T4) }\end{array}$ & $\begin{array}{l}\mathrm{TC} \\
(\mathrm{T} 5)\end{array}$ \\
\hline Dry m atter $(\%)$ & 94.58 & 97.02 & 94.24 & 94.31 & 93.11 \\
\hline $\begin{array}{l}\text { Crude protein } \\
(\%)\end{array}$ & 15.38 & 15.00 & 15.25 & 14.38 & 13.44 \\
\hline Crude fiber $(\%)$ & 11.43 & 11.02 & 10.62 & 11.21 & 11.89 \\
\hline extract & 2.09 & 2.10 & 3.11 & 2.87 & 3.77 \\
\hline Ash $(\%)$ & 8.21 & 3.49 & 4.81 & 5.62 & 4.38 \\
\hline *NFE (\%) & 62.89 & 68.39 & 66.21 & 65.92 & 67.52 \\
\hline $\mathrm{GE}(\mathrm{kcal} / \mathrm{kg})$ & 3455 & 3444 & 3452 & 3562 & 3571 \\
\hline
\end{tabular}

Table 3: E conom ic and Growth Perform ance of Rabbits Fed Raw and Processed Lablab purpureus Seed

Meal Diets

\begin{tabular}{|c|c|c|c|c|c|c|}
\hline Parameters & $\begin{array}{l}\text { Control } \\
\text { (T1) }\end{array}$ & $\begin{array}{l}\mathrm{TR} \\
(\mathrm{T} 2)\end{array}$ & $\begin{array}{l}\text { TD } \\
\text { (T3) }\end{array}$ & $\begin{array}{l}\text { TT } \\
\text { (T4) }\end{array}$ & $\begin{array}{l}\mathrm{TC} \\
(\mathrm{T} 5)\end{array}$ & SEM \\
\hline Initial weight (g) & 351.67 & 358.00 & 350.00 & 350.00 & 354.17 & \\
\hline Final weight (g) & $675.00^{\mathrm{a}}$ & $470.00^{\circ \mathrm{C}}$ & $445.00^{c}$ & $588.33^{30}$ & $615.00^{\mathrm{a}}$ & 24.14 \\
\hline Total weight gain (g) & $323.33^{\mathrm{a}}$ & $112.00^{\mathrm{C}}$ & $95.00^{c}$ & $238.33^{\mathrm{b}}$ & $260.83^{b}$ & 18.71 \\
\hline Daily feed intake (g) & $16.32^{b}$ & $15.81^{c}$ & $15.12^{c}$ & $21.45^{\mathrm{a}}$ & $21.76^{\mathrm{a}}$ & 0.72 \\
\hline Daily weight gain (g) & $9.24^{\mathrm{a}}$ & $3.20^{\mathrm{c}}$ & $2.71^{c}$ & $6.81^{b}$ & $7.45^{b}$ & 0.53 \\
\hline Feed/gain ratio & $1.77^{\mathrm{a}}$ & $4.94^{c}$ & $5.58^{c}$ & $3.15^{b}$ & $2.92^{\mathrm{b}}$ & 0.31 \\
\hline Cost/kg diet (AT) & 39.05 & 35.17 & 34.70 & 34.99 & 34.64 & - \\
\hline $\begin{array}{l}\text { Cost of feeding } \\
\text { to final weight }(A)\end{array}$ & 22.30 & 19.46 & 18.36 & 26.27 & 26.38 & - \\
\hline $\begin{array}{l}\text { Feed cost } \mathrm{kg} \text { live weight } \\
\text { gain (N) } \\
\text { Mortality (\%) }\end{array}$ & $\begin{array}{l}68.97 \\
0\end{array}$ & $\begin{array}{l}175.75 \\
33.33\end{array}$ & $\begin{array}{l}193.26 \\
0\end{array}$ & $\begin{array}{l}110.23 \\
0\end{array}$ & $\begin{array}{l}101.14 \\
0\end{array}$ & - \\
\hline $\begin{array}{l}\mathrm{abC} \text { - Mean values within a } \mathrm{r} \\
\mathrm{SEM} \text { - StandardError of } \mathrm{Me} \\
\mathrm{TR}=\mathrm{raw} \text { lablab seed diet } \mathrm{T} \\
\mathrm{TT}=\mathrm{T} \text { oasted lablab seed die }\end{array}$ & $\mathrm{n}$ with $\mathrm{s}$ & cooked lab & $\begin{array}{l}\text { aperscript } \\
\text { d diet } \\
\text { seed die }\end{array}$ & ot tife & $0.05)$ & \\
\hline
\end{tabular}




\section{Reference}

[1]. Chav-chifaicheung, P.C.K, Wang-Yunshingchan, C.F. and Wang, Y.S. Effect of cooking on content of amino nutrients of three Chinese indigenous legume seeds, Journal of Science, Food and Agriculture, 75: 1997) 447-452

[2]. Murphy, A.M and Colucci, P.E. A tropical forage solution to poor quality diets. A review of lablab purpureus. Livestock Research for Rural Developemt 11 (2) 1999. htt://www.c.pav.org.co//rrllrrd11/2/colu.112.ht

[3]. Cama, H.R. and R.A Morton, Changes occurring in the protein as a result of processing groundnut under selected industrial conditions. Br. 7 Nutri. 4; 1950 Pp 154-160

[4]. Ikurior, S.A, Torbee, S.A and Anthony, T. I. Effect of cooked or roasted full fat soyabean and soyabean meal onperformance and carcass characteristics of growing- finishing pigs. Journal Science Food and Agriculture, 69: 1993) 309-

[5]. Kaankuka, F.G., T.F. Balogun and I.D.I. Yaakugh, Effect of duration of cooking raw full fat soybeans on dug matter digestibility and energy utilization by young pigs. Proceedings of the Annual Conference of Nigeria Society for Animal Production held at Michael Okpara University of Agriculture $\quad$ Umudike, Nigeria: 2000) 191-193.

[6]. Tuleun C.D. and Patrick, J.P. Effect of duration of cooking mucuna utilis seed on proximate analysis, levels of antinutritional factors and performance of broiler chickens. Nigerian Journal of Animal Production. 34(1) 2007:45-53

[7]. Dzungwe, T.A. The Search for a Viable Benue State. Benue State Gazzette. 1991). Pp. 13-14.

[8]. Ikurior, S.A. Replacement of dietary soyabean meal protein with that from roasted or cooked full-fat soyabean for weaner-grower pigs. Trop. Oilseed J. 1(2) 2003: 90-97

[9]. Ogundipe, S.O, Abeke, F.O, Sekoni A.A, Dafwang, I.I. and Adeyinka I.A. Effect of cooking duration on the utilization of lablab purpureus beans by pullet chicks. In Proceedings of the 28th Annual Conference of Nigeria Society for Animal Production. 28: 2003). $233-234$

[10]. Gege, B. M. Biochemical and nutritional responses of broiler chickens to raw, soaked and cooked lablab purpureusseeds. MSc. Thesis submitted to The Department of Animal Production, University of Agriculture Makurdi, Nigeria. 2008

[11]. Ogundipe, S.O., Effects of boiling and boiling/roasting on subsequent utilization of soyabeans by chickens. Ph.D Dissertation. Michigan State University. East Lansing Michigan USA. 1980

[12]. Amaefule K U and Obioha F C. Performance and nutrient utilization of broiler starters feed diets containing raw, boiled ordehulled pigeon pea seeds (Cajanus cajan) Nigerian Journal of Animal Production. 28: 200131 - 39.

[13]. Esuno, B. O. Substitution value of mixture of rice milling by-products for maize in diets of weaner rabbits. Nigerian Journal of Animal Production 24(2) 1997:143-144

[14]. Biobaku, W. O., Akinsanmi, S. K. and Sodimu, O. A. Effect of copper sulphate supplementation on rabbit performance under Nigerian condition. Trop. J. Anim. Sci. 1(1) 1999; 141-146

[15]. Aduku, A.O. Tropical Feedstuffs Nutrient Analysis Table. Ahmadu Bello University, Zaria, Nigeria. 1993. 2pp.

[16]. D' Mello, J.P.F and Devandra, C. Tropical Legumes in Animal Nutrition: 1995) 67 - 191.

[17]. Amaefule, K.U and Nwagbara, N.N. The effect of processing of Pigeon pea (Cajanus cajan) seed meal and Pigeopea seed meal based diets by pullets. International Journal of Poultry Science 3 (8): 2004) 543-546

[18]. Aletor, V.A. Allelochemical in plant food and feedingstuff, nutritional biochemical and physiopathological aspects in animal production. Vet. Hum. Toxicol. 35: 1993) 57-67

[19]. Aletor, V. A. Anti-nutritional Factors as Nature's Paradox in Food and Nutrition Securities. Inaugural Lecture series 15 organized by The Federal University of Technology, Akure, on Thursday,August 12,1999: 10-15

[20]. Cheeke, P. R., Whanger, P. D. and Amberg, J. Comparative calcium excretion by rats and rabbits. J. Anim Science 37: 1982) 450-454. 